\title{
Teološka antropologija pred izazovom (evolutivne) kognitivne znanosti o religiji
}

\author{
SAŠA HORVAT* ${ }^{*}$ - RICHARD PAVLIĆ ${ }^{* *}$ \\ • https://doi.org/10.31823/d.28.3.1 • \\ UDK: 27-11-18 • Izvorni znanstveni rad \\ Primljeno: 3. ožujka 2020. • Prihvaćeno: 8. rujna 2020.
}

${ }^{*}$ Doc. dr. sc. Saša Horvat, Katolički bogoslovni fakultet

Sveučilišta u Zagrebu,

Teologija u Rijeci -

Područni studij Katoličkoga

bogoslovnog fakulteta

Sveučilišta u Zagrebu,

Omladinska 14,

51000 Rijeka, Hrvatska,

horvat.sasa@gmail.com

${ }^{* *}$ Doc. dr. sc.

Richard Pavlić, Katolički

bogoslovni fakultet

Sveučilišta u Zagrebu,

Teologija u Rijeci -

Područni studij Katoličkoga

bogoslovnog fakulteta

Sveučilišta u Zagrebu,

Omladinska 14,

51000 Rijeka, Hrvatska,

ripavlic@gmail.com

Sažetak: Autori u radu analiziraju osnovne odrednice relativno mladih znanstvenih disciplina nazvanih kognitivna znanost o religiji $i$ evolutivna kognitivna znanost o religiji, koje su postale nezaobilazne pri pokušaju ostvarenja znanstvenoga objašnjenja religije. Cilj je članka pružiti širi okvir razumijevanja mogućega budućega razvoja interdisciplinarnoga i transdisciplinarnoga dijaloga izmedu novih disciplina i teološke antropologije.

Ključne riječi: kognitivna znanost o religiji, teološka antropologija, religioznost, evolucija, redukcija, interdisciplinarnost, Bog.

\section{Uvod}

Znanstvena teorija o religiji u zadnjih nekoliko desetljeća zadobila je novi impuls na području mladih disciplina nazvanih kognitivna znanost o religiji i evolutivna kognitivna znanost o religiji. Postavlja se pitanje odnosa navedenih disciplina s jedne strane te teološke antropologije s druge strane. S obzirom na to da prema našim saznanjima zasad na hrvatskom govornom području nije bilo pokušaja razvoja toga odnosa, cilj je ovoga rada pripremiti osnovni okvir za mogućnost razvoja interdisciplinarnoga i transdisciplinarnoga dijaloga između navedenih disciplina. U prvom koraku izložit ćemo osnovne značajke (evolutivne) kognitivne znanosti o religiji u vidu polja 
istraživanja, metoda i problematike istraživanja u smislu temeljnih hipoteza, dotičući se pitanja redukcije i odnosa s drugim znanostima. U drugom koraku pružit ćemo širu kontekstualizaciju teološke antropologije i njezinih dosadašnjih odnosa sa znanstvenim razumijevanjem religije. U zaključku ćemo ponuditi sintezu izrečenoga, radi ostvarenja jednoga prologa za budući interdisciplinarni i transdisciplinarni dijalog.

\section{Uvod u (evolucijsku) kognitivnu znanost o religiji}

Brojne znanstvene discipline zajedničkim snagama, posuđujući uvide, ideje i hipoteze jedne od drugih, nastoje osmisliti jedinstvenu znanstvenu teoriju o religiji i njezinoj evoluciji. Međutim zasad takva teorija nije postavljena ${ }^{1}$ niti se čini kako bismo u skorašnje vrijeme mogli svjedočiti tom uspjehu. Teolog Lluis Oviedo prije tri godine ponudio je prvi sustavni prikaz 75 glavnih objavljenih znanstvenih istraživačkih pokušaja razumijevanja ljudskoga vjerovanja. S obzirom na golem interes za religioznost kao jedinstven ljudski fenomen, ${ }^{2}$ broj je do današnjega dana zasigurno narastao. ${ }^{3}$ Suvremeni naturalistički pokušaj objašnjenja nastanka, razvoja i sveprisutnosti ljudske religioznosti odlikuje se pluralizmom znanstveno podržanih

${ }^{1}$ Usp. L. OVIEDO, Introduction. A Multilevel and Multidisciplinary Approach to Understanding Religion and Its Evolution, u: J. R. FEIERMAN, ISTI (ur.), The Evolution of Religion, Religiosity and Theology. A Multilevel and Multidisciplinary Approach, London, 2019., 1-19., ovdje 2.

${ }^{2} \mathrm{U}$ prilog opširnosti i kompleksnosti znanstvenoga istraživanja religioznosti govore i istraživačke hipoteze o protoreligioznim obrascima ponašanja kod životinja, koji u evolutivnoj perspektivi prethode i pospješuju razvoj ljudske religioznosti. Protoreligiozni obrasci uočavaju se kod sisavaca s velikim mozgom, na primjer sposobnost empatije, preuzimanje uloga i osjećaja za sebstvo kod velikih majmuna ili u ritualnom ponašanju čimpanza. Usp. J. H. TURNER, A. MARYANSKI, A. K. PETERSEN, A. W. GEERTZ, The Emergence and Evolution of Religion. By Means of Natural Selection, New York, 2018., 107. i dalje. Bez daljnjega je upitno koliko se pojmovi kao religioznost, ritual ili sebstvo, pa i uz prefiks proto, mogu dovoditi u vezu s ponašanjima vrsta koje ne poznaju nezaobilazni moment govora o navedenim iskustvima, a koji je plod (samo)refleksije. Kao jedinstveno ljudski fenomen, subjekt promišlja i postavlja samoga sebe kao objekt te je istodobno svjestan vlastitoga čina. Pierre Teilhard de Chardin istaknut će kako je to trenutak u ljudskom rodu kada se $\gg$ misao rađa «. Usp. P. T. de CHARDIN, The Phenomenon of Man, New York, 1965., 165./180. Problematika znanstvenoga istraživanja religioznosti poznaje i dodatni sloj pitanja o tome jesu li samo moderni ljudi religiozni ili su i davni pripadnici neandertalaca i denisovskoga čovjeka također pokazivali protoreligiozne obrasce ponašanja? Više u: R. N. MCCAULEY, Are Modern Human Beings the Only Species with Religion?, 4. studenoga 2018. Dostupno na: https://www.psychologytoday.com/intl/ blog/why-religion-is-natural-and-science-is-not/201811/are-modern-human-beings-the-onlyspecies (15. 1.2020.).

${ }^{3}$ Usp. L. OVIEDO, Recent Scientific Explanations of Religious Beliefs: A Systematic Account, u: H.F. ANGEL, ISTI, R. F. PALOUTZIAN, A. RUNEHOV, R. J. SEITZ (ur.), Processes of Believing: The Acquisition, Maintenance, and Change in Creditions, Cham, 2017., 289-318. 
paradigmi $^{4}$, uz pomoć kojih se nastoje utemeljiti barem početni okviri i putokazi razumijevanja. Dodatno otežavajuća činjenica jest kompleksnost samoga fenomena religioznosti, koja se kroz cijelu ljudsku povijest očituje u gotovo nepreglednim izražajnim oblicima, od primitivnih rituala do suvremenih religioznih obreda, svakodnevnih molitvi i svetopisamskih tekstova, religijskih struktura unutar društva itd.

Većina istraživanja polazi od ispitivanja jedne forme religioznosti pripisujući joj određenu funkciju, filozofsko-teološki rečeno - svrhu, koja se onda promatra isključivo unutar perspektive discipline koja je zahvaća. Pristup koji kreće od pojedinačnih formi prema općim zaključcima o ljudskoj religioznosti - bottom-up - ne može zaobići reduktivni način promatranja i zaključivanja. Međutim postoje i pokušaji koje se može okarakterizirati kao deduktivne - top-down, kada se na primjer istražuje na koji se način odvija prijenos kulturnih formi, uključujući i religioznu, društvenim učenjem. ${ }^{5}$ Pitanje redukcije ipak nije nužno negativno jer, u konačnici, svi su znanstveni pokušaji reduktivni. To proizlazi iz činjenice da znanost za proučavanje nužno odabire jedan ili više od mnogih dostupnih fenomena unutar nekoga polja istraživanja. ${ }^{6} \mathrm{O}$ toj temi malo više u nastavku poglavlja.

Evolucijske, neuroznanstvene i kognitivne perspektive relativno su mladi znanstveni pogledi i trenutačno nude dominirajuću paradigmu u znanstvenoj potrazi za ključem razumijevanja čovjeka i njegove religioznosti. Unatoč tomu oni pokazuju potencijal u postavljanju ozbiljnih izazova za filozofe, teologe i ostale društvenohumanističke znanosti koje promišljaju ljudsko biće kao takvo i njegovu religioznost. $^{7}$

Prije svega, izazov se očituje u tome da pojedini autori smatraju kako će evolucijske, neuroznanstvene i kognitivne perspektive ponuditi konačni odgovor na pitanje što je čovjek. Razumijevajući čovjeka i svijet a priori u isključivo fizikalističkom okviru, i u antropološkom i u metafizičkom smislu, sva ljudska ostvarenja promatraju se kroz evolutivnu prizmu prirodnoga odabira i preživljavanja pojedinca, obitelji, zajednice ili vrste. U tom kontekstu se i religioznost promatra kao usputni moment evolucijskoga razvoja čovjeka, njegova mozga i kognitivnih sposobnosti. Religioznost i religija tako su fenomeni koji su na neki način bili korisni čovjeku tije-

\footnotetext{
${ }^{4}$ Paradigme kao što su kulturna evolucija, društvena psihologija, sociologija, neuroznanosti, kibernetika i teorija informacija te brojne druge. Usp. L. OVIEDO, Introduction, 3.

${ }^{5}$ Usp. isto, 2.

${ }^{6}$ Usp. R. N. MCCAULEY, E. T. LAWSON, Philosophical Foundations of the Cognitive Science of Religion, London, 2019., 4.

${ }^{7}$ Usp. Ž. TANJIĆ, Riječ teologije u vrtlogu znanosti, u: ISTI, Teologija pred izazovima sadašnjeg trenutka, Zagreb, 2009., 37.
} 
kom nemilosrdne borbe za očuvanje vrste. ${ }^{8} \mathrm{~S}$ obzirom na to da je prirodno nastala, evoluirala i održala se, smatra se kako nema potrebe ljudsku religioznost dodatno objašnjavati natprirodnim elementima. ${ }^{9}$ Drugim riječima, čovjek je religiozan zbog evoluiranoga kognitivnoga sklopa, zbog čega božansko - u svim svojim mogućim oblicima - postaje suvišno. Razumljivo je zašto se jedno od vodećih pitanja suvremenih interdisciplinarnih dijaloga bavi mogućnostima sinteze filozofsko-teoloških spoznaja o čovjeku i novih perspektiva razvijenih u evolucijskom okviru.

Evolucijske, neuroznanstvene i kognitivne perspektive ljudske religioznosti zasebne su discipline koje svoj zajednički jezik razvijaju na područjima koja se zovu: kognitivna znanost o religiji (the cognitive science of religion - CSR) i evolutivna kognitivna znanost o religiji (the evolutionary cognitive science of religion - ECSR). Namjera je ovoga dijela rada ukratko izložiti osnovne ciljeve, metodologije i hipoteze navedenih disciplina. ${ }^{10}$

Prema Robinu Dunbaru, pitanja religije i ljudske religioznosti u teorijama evolucijskih biologa bila su zapostavljena još od Darwinova vremena. Međutim u zadnjih nekoliko desetljeća upravo spomenuta pitanja ulaze na velika vrata u znanstvena istraživanja. Naime, ako se želi evolucijski razumjeti ljudsku vrstu, kako objasniti činjenicu da su pripadnici svih nama poznatih ljudskih zajednica, od najprimitivnijih oblika do razvijenih društava, prakticirali neki oblik religioznoga ponašanja, što onda implicira i određeni oblik religioznoga vjerovanja? Skraćeno rečeno, koja je uloga religioznosti i religije u evolutivnom razvoju ljudskoga bića? ${ }^{11}$ Tako od početnoga ignoriranja činjenica ljudske religioznosti u evolutivnim promišljanjima po-

\footnotetext{
${ }^{8}$ Više o znanstvenom razumijevanju religije u perspektivi njezine koristi i smisla, usp. L. OVIEDO, Meaning and Religion: Exploring Mutual Implications, u: Scientia et Fides 7(2019.)1, 25-46.

${ }^{9}$ Usp. P. BOYER, Religion Explained: The Evolutionary Origins of Religious Thought, London, 2002.

${ }^{10} \mathrm{~S}$ obzirom na to da je riječ o disciplinama u nastajanju postoje određene poteškoće i nejasnoće što se tiče definiranja standardnih metoda, metodologija i ciljeva tih disciplina. Problematika izlazi iz okvira namjera ovoga rada, ali za kritički pristup tomu problemu, više u: J. JONG, How Not to Criticize the (Evolutionary) Cognitive Science of Religion, 11. studenoga 2014. Dostupno na: https://marginalia.lareviewofbooks.org/criticize-evolutionary-cognitive-science-religion/ (16. 1 . 2020.).

${ }^{11}$ Za više o odnosu teološke misli i znanosti/evolucije, vidi u: N. BIŽACA, J. DUKIĆ, J. GARMAZ, Kršćanstvo i evolucija, Split, 2010.; J. BALABANIĆ, Neočitost Božje prisutnosti u svijetu, u: Nova prisutnost: časopis za intelektualna i duhovna pitanja 5(2007.)3, 389-416.; T. MATULIĆ, Teologija i evolucijska biologija. Promišljanje o nekim poticajima Ivana Pavla II. za dijalog između teologije i teorije evolucije, u: Bogoslovska smotra 72(2002.)4, 655-680.; P. ROSZAK, T. HUZAREK, Seeing God. Thomas Aquinas on Divine Presence in the World, u: Bogoslovni vestnik 79(2019.)3, 739749 .
} 
staje nezaobilazna tema ili - riječima spomenutoga Dunbara - evolucija pronalazi Boga. ${ }^{12}$

Što je to dakle kognitivna znanost o religiji? Riječ je o znanstvenoj disciplini koja za cilj ima istražiti religiozna vjerovanja i prakse promatrajući ih kao proizvode (posljedice) uobičajenih procesa ljudske spoznaje, a ne kao neku zasebnu dimenziju ljudske spoznaje. Znanstvenici koji djeluju na tom polju smatraju kako će zadobiveni uvidi omogućiti bolje razumijevanje fenomena religioznosti. ${ }^{13}$

Tri su glavne pretpostavke kognitivne znanosti o religiji. ${ }^{14}$ Prvo, za razliku od ostalih pristupa religioznosti, smatra se da je religioznost posljedica uobičajenih kognitivnih procesa te da nastaje jako rano u razvoju čovječanstva. Religioznost kao takva nije ovisna o kulturi, što se pokazuje u činjenici da djeca samostalno oblikuju mišljenje o životu nakon smrti. Ujedno, istraživanja su pokazala kako djeca mogu predmete i događaje u svijetu shvaćati kao proizvode neljudskoga djelovanja koji imaju svoju svrhovitost. Djeca su tako nazvana $\gg$ intuitivni teisti $<{ }^{15}$ Drugo, kognitivna znanost o religiji drži kako je objašnjenje religioznosti, kao i ljudske kulture, nužno utemeljeno u kognitivnoj znanosti. Naime kognitivna predispozicija za religiozno ponašanje, kao i kulturni prijenos tih obrazaca važni su u razvijanju znanstvene teorije zašto ljudi vjeruju. Religiozna vjerovanja na neki način odraz su naših kognitivnih sposobnosti. Na primjer jedna hipoteza drži kako se ljudsko vjerovanje u život nakon smrti razvilo jer čovjek nije mogao zamisliti da više ne postoji. Tomu je pridonijela i teorija uma koja proučava ljudsku sposobnost da domišlja tuđe mišljenje na temelju razumijevanja vlastitoga. Treće, kognitivni mehanizmi razvili su se tijekom evolutivnoga procesa ${ }^{16}$. $U$ temelju ljudske religioznosti jest evolutivna kognitivna arhitektura sa svojim sposobnostima. Tako nastaje novo polje istraživanja - evolutivna kognitivna znanost o religiji (the evolutionary cognitive science of religion - ECSR). Religiozni fenomeni promatraju se kao rezultat jedinstvene

${ }^{12}$ Usp. R. DUNBAR, Belief special: How evolution found God, 25. siječnja 2006. Dostupno na: https://www.newscientist.com/article/mg18925361-100-belief-special-how-evolution-found-god/ (20. 1. 2020.).

${ }^{13}$ Usp. J. D. SMEDT, H. D. CRUZ, The Challenge of Evolution to Religion, Cambridge, 2020., 46.

${ }^{14}$ Usp. isto, 47. i dalje.

${ }^{15}$ Usp. D. KELEMEN, Are Children $\gg$ Intuitive Theists «? Reasoning About Purpose and Design in Nature, u: Psychological Science (2004.)15, 295-301.; N. A. EMMONS, D. KELEMEN, The development of children's prelife reasoning: evidence from two cultures, u: Child Development 85(2014.)4, 1617-1633.

${ }^{16}$ Nezaobilazna je i činjenica složenosti razumijevanja evolucije i njezinih mehanizama. Usp. E. JABLONKA, M. J. LAMB, Evolution in Four Dimensions: Genetic, Epigenetic, Behavioral, and Symbolic Variation in the History of Life, Cambridge, 2005. U ovom radu nemamo prostora za analizu kako razumijevanje evolucije i mehanizama povratno utječe na znanstvenu sliku o religiji. 
ljudske evolutivne povijesti te im se pristupa ili kao nusproizvodima evoluiranih kognitivnih mehanizama, ili kao adaptaciji (koja uključuje kognitivne, afektivne, bihevioralne i razvojne elemente), ili iz obiju navedenih perspektivi.

Američki kognitivni znanstvenik Justin Barrett drži kako je disciplina izazovna za istraživače zbog triju postavki: izbjegavajući definirati pojam religije, identificira ljudske misli i oblike ponašanja koji bi se mogli okarakterizirati kao religiozni te pokušava objasniti zašto se oni pojavljuju u brojnim društvima; zahvaljujući takvom pristupu, otvoreni su za istraživače iz raznih znanstvenih polja; razvija se metodološki pluralizam radi prikupljanja što veće količine podataka i analitičkih metoda, kako bi se otkrilo u čemu se temelji činjenica međukulturnoga i povijesno redovitoga pojavljivanja religioznih kognitivnih činova. ${ }^{17}$

Kognitivna znanost o religiji i evolutivna kognitivna znanost o religiji proučavaju brojne religiozne fenomene i o njima postavljaju vlastite hipoteze. Neke smo već naveli, no navedimo još nekoliko primjera koji su obuhvaćeni eksperimentalnim istraživanjima: zašto se utvrđenim teološkim naukom koji znaju i prihvaćaju, kao na primjer da je kršćanski Bog svemoguć, sveznajući i sveprisutan, ispitanici u spontanim odgovorima ne koriste i ne primjenjuju ga, nego daju teološki nekorektne tvrdnje (theological incorrectness); zašto su bitni rituali koji mogu biti na određenu štetu za onoga koji sudjeluje i što time sudionik poručuje svojoj grupi (costly signaling); zašto se religiozna uvjerenja lako dalje prenose na druge ljude - je li zbog toga što su upečatljiva i lako se pamte jer ih odlikuje minimalna kontraintuitivnost (minimally counter-intuitive religious representations) - na primjer da duše prolaze kroz zidove; zašto je u svim religijama prisutno vjerovanje u nadnaravna bića - možda zato što su oni ljudima izuzetno bitni u svakodnevnim društvenim odnosima, moralu, u pitanjima smrti ili nesreće; je li se vjera u nadnaravna bića razvila iz kognitivne sposobnosti koja nam je pomogla u preživljavanju jer smo bili preosjetljivi na sve podražaje iz okoline, kao da su od nekoga bića prouzročene (hypersensitive agency detection device (HADD)). Naime imamo veće šanse za preživjeti ako šuškanje $\mathrm{u}$ grmu shvatimo kao znak za opasnost jer je uzrok neki subjekt - možda čak grabežljivac, nego ako šuškanje zanemarimo. Stoga, je li spomenuti kognitivni mehanizam doveo do rođenja i razvoja ideje boga, kao nužne potrebe osmišljavanja uzroka neobjašnjivih ili velikih prirodnih događaja (poplave, sunce, oluje...) ? $^{18}$

\footnotetext{
${ }^{17}$ Usp. J. L. BARRETT, Cognitive Science of Religion: What Is It and Why Is It?, u: Religion Compass 6(2007.) 1, 768-786., ovdje 768-769.

${ }^{18}$ Usp. D. J. SLONE, W. W. MCCORKLE Jr. (ur.), The Cognitive Science of Religion: A Methodological Introduction to Key Empirical Studies, London, 2019.; usp. A. VISALA, Naturalism, Theism and the Cognitive Study of Religion: Religion Explained?, London, 2011., 55. i dalje.; usp. R. N. MCCAULEY, E. T. LAWSON, Philosophical Foundations of the Cognitive Science of Religion, 130. i dalje.; usp. J. A. van SLYKE, The Cognitive Science of Religion, Oxfordshire, 2016.
} 
Navedene discipline koriste se spoznajama iz različitih polja, kao što su kognitivna psihologija, religiozne studije, filozofija uma, neuroznanosti, iz društvene, kulturne i kognitivne antropologije itd. ${ }^{19}$ Riječ je o istraživanju koje svoje metode, eksperimentalne tehnike, analize, ideje ili hipoteze crpi iz svih dostupnih znanstvenih sustava, uključujući teologiju i filozofiju. Navedena istraživanja postavljaju izazove ne samo pred teologiju i filozofiju nego i pred druge discipline te se postavlja pitanje umanjuju li rezultati koje su ostvarili kognitivna znanost o religiji i evolutivna kognitivna znanost o religiji razumnost i opravdanost religije. Ako nove spoznaje uopće izazivaju religiju, na koji se način to realizira? ${ }^{20}$

Ako znanstvenik na polju (evolutivne) kognitivne znanosti o religiji sebi ne postavlja za cilj potpuno rješenje ljudske religioznosti, onda uviđa da teologija, kao i recimo biologija, ima mnogo toga za ponuditi njegovu istraživanju. Međutim ujedno se uviđa, a to je izrazito bitno, kako teologija i biologija imaju vlastitu i opravdanu interpretaciju religioznoga fenomena. Bogatstvo različitih znanstvenih disciplina omogućuje bolju kontekstualizacijsku strategiju religioznoga fenomena. Suvremeni znanstveni pogled na ljudsku religioznost sve više uviđa kako je religioznost explanandum koji se proteže kroz različite znanstvene discipline, od molekularne do društvene razine te se njezina kompleksnost i objašnjenje ne iscrpljuju u samo jednom ili dvama znanstvenim poljima. To ujedno znači da paradigme i spoznaje jedne znanstvene discipline ne vode eliminaciji druge znanstvene discipline niti se toga treba bojati. ${ }^{21}$

Nakon što smo ukratko predstavili nove znanstvene discipline, sada prelazimo na područje teološke antropologije, koja će nam pružiti uvid u dosadašnje pokušaje i izazove odnosa sa znanstvenom slikom religioznosti, širi kontekst razumijevanja moguće buduće suradnje dvaju polja.

\section{Teologija stvaranja}

Teologija stvaranja čini sastavni dio teološke discipline koju nazivamo teološka antropologija. Sama sintagma teološka antropologija nužno nameće dijalošku per-

\footnotetext{
${ }^{19}$ Usp. L. TURNER, Introduction: Pluralism and Complexity in the Evolutionary Cognitive Science of Religion, u: F. WATTS, L. TURNER (ur.), Evolution, Religion, and Cognitive Science. Critical and Constructive Essays, Oxford, 2014., 1-20., ovdje 2.

${ }^{20}$ Za moguće odgovore na postavljena pitanja, vidi više u: H. D. CRUZ, R. NICHOLS, Introduction: Cognitive Science of Religion and Its Philosophical Implications, u: H. D. CRUZ, R. NICHOLS (ur.), Advances in Religion, Cognitive Science, and Experimental Philosophy, London, 2016., 1-19., ovdje 7.

${ }^{21}$ Usp. R. N. MCCAULEY, E. T. LAWSON, Philosophical Foundations of the Cognitive Science of Religion, 15. i dalje.
} 
spektivu, u ovom slučaju teologije i antropologije. Sama pak teologija sa svojim pridjevom humanističke znanosti nužno se bavi čovjekom, i to u perspektivi njegove stvorenosti i odnosnosti s Bogom. ${ }^{22}$

Objekt kršćanske antropologije jest istina o čovjeku koja se temelji na kršćanskoj objavi. Ovdje temeljno pitanje nije dakle što je čovjek u sebi samome, nego što je čovjek u svom odnosu prema Bogu, prema drugom čovjeku, svijetu i sebi samome. U tom kontekstu čovjekove višestruke odnosnosti razmatra se pitanje čovjekova početka, njegove otajstvene stvorenosti, zatim pitanje čovjekova konačnoga cilja, smisla njegova postojanja te pitanje čovjekove egzistencijalne krhkosti i uvjetovanosti grijehom.

Glede čovjekove stvorenosti, kršćanska antropologija uzima za polazište biblijsku antropologiju. U njoj pak ne nalazimo sustavno antropološko promišljanje, ali nalazimo bitne teološko-antropološke elemente koji će biti polazište za daljnji razvoj kršćanske antropologije. Temeljna antropološka perspektiva Staroga zavjeta sažima se u pojmu čovjeka - slike Božje (Post 1, 26-27). Tim se biblijsko-teološkim pojmom istovremeno jamče dva antropološka temelja: Božja apsolutna transcendencija u odnosu na stvorenje te čovjekova konstitutivna upućenost na Stvoritelja. Usporedno sa središnjom idejom čovjekove bogolikosti, u Starom zavjetu možemo izdvojiti četiri bitna elementa koja nam pomažu u razumijevanju starozavjetne antropologije. To su hebrejski pojmovi: basar - 'meso', nefeš - 'duša', ruah - 'duh' te leb - 'srce.' Unatoč pojmovnoj raznolikosti, sva ta četiri elementa upućuju na čovjeka shvaćenoga kao kompleksno, ali i jedinstveno i cjelovito biće, konstitutivno upućeno na Boga Stvoritelja kao konačni cilj i svrhu svoga postojanja. ${ }^{23}$

Ovu konstitutivnu upućenost na Boga ugrožava, ali ne dokida čovjekova egzistencijalna krhkost ili slabost. Ona je slikovito opisana u trećoj glavi Knjige Postanka (Post 3, 1-24), a teološki formulirana pojmom grijeha. Uvjetovanost grijehom ugrožava, ali ne dokida čovjekovu relacijsku sposobnost u svom horizontalnom i vertikalnom aspektu: čovjek - čovjek, čovjek - Bog. Čovjekova trajna obilježenost grijehom biva objektom njegove konstantne životne borbe oko postizanja svoga konačnoga cilja u Bogu.

Na takvu teološko-antropološku postavku Staroga zavjeta nastavlja se novozavjetna antropologija koja u osobi Isusa Krista prepoznaje puninu objave, puninu objavljene istine o Bogu i čovjeku. Najveću koncentraciju novozavjetnih antropoloških

\footnotetext{
${ }^{22}$ Usp. I. SIVIGLIA, Antropologia teologica in dialogo, Bologna, 2007.

${ }^{23}$ Usp. R. PAVLIĆ, Antropologija sv. Pavla, u: PAPINSKI HRVATSKI ZAVOD SVETOG JERONIMA, Apostolu naroda, Zbornik radova svećenika studenata Papinskoga hrvatskog zavoda sv. Jeronima o sv. Pavlu u njegovu jubileju, Ž. Majić (ur.), Rim, 2009., 96-99.
} 
elemenata nalazimo u Ivanovim i Pavlovim spisima. Kod Pavla, u takozvanom corpus paulinum, nalazimo odjek spomenutih hebrejskih starozavjetnih pojmova, ali ovdje u ruhu grčkoga jezika: soma - 'tijelo', sarx - 'meso', psyche - 'duša', pneuma - 'duh', kardia - 'srce', nous - 'um'. I u ovom slučaju pojmovna raznolikost i višeznačnost ne ugrožavaju biblijski kontinuitet u poimanju čovjeka kao jedinstvenoga $\mathrm{i}$ cjelovitoga bića, u različitim životnim okolnostima i stanjima, te kontinuitet vjere u jedinstvenoga Boga stvoritelja. ${ }^{24}$

\subsection{IZAZOVI KRŠĆANSKOJ ANTROPOLOŠKOJ VIZIJI}

Takva jedinstvena kršćanska vizija čovjeka kao cjelovitoga i jedinstvenoga bića svoj prvi izazov nalazi u susretu s helenističkom mišlju i kulturom koje biblijskom pojmu stvaranja iz ničega (ex nihilo) nameću ideju vječnosti materije, a kršćanskom poimanju čovjeka kao jedinstvenoga i cjelovitoga bića nameću dualističku antropologiju platonističkoga tipa. Ovdje se čovjeka poima kao biće satkano od dvaju temeljnih konstitutivnih elemenata: tijela i duše, pri čemu se duši daje prednost nad tijelom. ${ }^{25}$

Još veći izazov kršćanskoj antropološkoj viziji predstavljaju gnostičke inačice antropološkoga dualizma te posljedični prijezir tijela koji bitno ugrožava kršćansku jedinstvenu antropološku viziju. Sve su te početne izazove na različite načine prevladali prvi kršćanski apologeti koji vraćaju na biblijsku viziju čovjeka kao cjelovitoga i jedinstvenoga bića. ${ }^{26}$

Evolucijski izazovi kršćanskoj antropološkoj viziji javljaju se paralelno s razvojem novovjekovne misli o čovjeku i susreta kršćanske antropologije s prirodnim znanostima. U tom kontekstu možemo izdvojiti tri bitna izazovna momenta. Prvi je radikalni dualizam Renea Descartesa 17. stoljeća prema kojemu um zauzima mjesto duše te je kao takav neprikladan za znanstveno istraživanje, dok je tijelo podložno istraživanjima znanosti kao što su biologija i fizika. Drugi izazovni moment jest početak Darwinove revolucije u biologiji 19. stoljeća kojim se postavljaju temelji za teoriju evolucije i današnji evolucionizam kojim se inzistira na isključivo materijalnom poimanju teorije evolucije te potpunom nijekanju Božjega stvaralačkoga djelovanja. Treći izazov javlja se krajem dvadesetoga i početkom dvadeset i prvoga stoljeća s razvojem kognitivnih i neuroznanosti zajedno s filozofijom uma, unutar

\footnotetext{
${ }^{24}$ Usp. isto.

${ }^{25}$ Usp. R. PAVLIĆ, K. KEVRIĆ, Stvaranje čovjeka u svjetlu kršćanske antropologije i susreta s prirodnim znanostima, u: Riječki teološki časopis 23(2015.)2, 365-388., ovdje 372-375.

${ }^{26}$ Usp. isto.
} 
kojih se rađa mišljenje da su »funkcije i karakteristike koje su se nekoć pripisivale duši (i duhu) zapravo samo funkcije mozga, odnosno dijela tijela $\ll^{27}$.

U kontekstu spomenutih izazova govor o smislu čovjekova života kao nekom konačnom cilju koji bi izlazio iz okvira zadane materijalističko-redukcionističke naravi ne dolazi u obzir. Samim time teološka tema grijeha kojim biva ugrožen čovjekov nadnaravni konačni cilj postaje potpuno irelevantna. Cinjenica postojanja zla te osjećaja krivnje suvremenoga čovjeka pokušava se tumačiti u kontekstu društvenih znanosti kao iluzija ili kompleks te se smješta u područje statističke analize u kojem se razlikuje redovito ponašanje od onoga koje izlazi iz okvira redovitoga. Takvim svođenjem na kvantitativno napušta se ideja moralnosti, a pojam vlastite odgovornosti biva marginaliziran.

Pojavom spomenutih antropoloških izazova suvremene antropološke perspektive mogu se prema nekim autorima svrstati u dvije optike koje možemo nazvati sljedećim imenima: antropološko-ekscentrična perspektiva kojoj odgovara religijski pristup čovjeku te antropološko-koncentrična perspektiva kojoj odgovara sekularni pristup čovjeku. ${ }^{28}$

Prvoj perspektivi svojstven je spomenuti biblijsko-teološki pristup čovjeku, u kojem se čovjeka pokušava razumjeti kroz prizmu objave u njegovoj otvorenosti i radikalnoj upućenosti na transcendenciju. Razvojem teološke antropologije biblijska ideja čovjeka - slike Božje imat će odjeka u snažnom teološko-antropološkom poj$\mathrm{mu}$ osobe. Oba pojma paralelno jamče teološko-antropološku ravnotežu. S jedne strane afirmiraju čovjekovo ontološko dostojanstvo te njegovu posebnost u odnosu na ostatak stvorenja. S druge strane čuvaju čovjeka od prevelike uznositosti ili autodivinizacije koje po sebi predstavljaju bît grijeha. Tim se pristupom nadalje jamči čovjekova naravna - stvorenjska samostojnost i cjelovitost, uz istovremenu afirmaciju njegove teologalno-ekscentrične otvorenosti za nadnaravno - transcendenciju. $^{29}$

Druga antropološka perspektiva svojstvena je sekularnom antropološkom pristupu čiji se korijeni nalaze u spomenutim antropološkim izazovima koji se javljaju počevši od 17. stoljeća do danas. Riječ je o tzv. koncentrično-empirijskom pristupu čovjeku kojim se čovjeka pokušava razumjeti u njegovim biološkim te psihosociološkim segmentima. Ekstremni oblici takvoga pristupa predstavljaju pokušaje reduciranja, koncentriranja čovjeka na njegove pojedine vidove iz kojih bi se tu-

\footnotetext{
${ }^{27}$ Usp. isto, 379-382.

${ }^{28}$ Usp. D. ŠIMUNEC, Homo simpliciter ili Imago Dei. Od područne bio-psiho-socijalne koncentričnosti do ekscentrično-teologalne cjelovitosti čovjeka, u: Bogoslovska smotra 86(2016.)1, 115-142.

${ }^{29}$ Usp. isto, 116-124.
} 
mačila cjelina. Takvi ekstremni pokušaji - koji danas možda nisu toliko dominantni - poprimaju oblike monističkih bilologizama, psihologizama i sociologizama koji znaju biti više ideološki nego činjenično potkrijepljeni. Koncentričnim antropološkim pristupom biva reduciran i spomenuti teološko-antropološki pojam osobe, on više ne predstavlja nešto što bi nadilazilo empirijsku uhvatljivost i zatvorenost, nego se svodi na puku psihosocijalnu razinu očigledne pojavnosti i funkcioniranja te poprima izraze osobnosti ili individualnosti. Tim pojmovima više se ne želi pojmiti ništa od teološko-antropološke integracije koja bi upućivala na teološki pojam osobe - slike Božje, nego se ono eventualno duhovno-transcendentno u čovjeku svodi na puko psihosociološko, idejno - umjetničko - kulturološko, zatvoreno u puku horizontalnost. ${ }^{30}$ Upravo složenost fenomena ljudske religioznosti opravdava trud i napore (evolutivne) kognitivne znanosti o religiji u razumijevanju toga fenomena. Tu se uvijek krije prava opasnost redukcionizma. Međutim jačanje svijesti o kompleksnosti samoga fenomena pridonosi uviđanju važnosti ostalih disciplina i njihovih uvida.

\subsection{EVOLUCIJSKI IZAZOVI}

Iz perspektive kršćanske antropologije danas bez straha možemo reći da sama teorija evolucije, koja je osnovna perspektiva promišljanja u (evolutivnoj) kognitivnoj znanosti o religiji, ne ugrožava kršćansku antropološku viziju, štoviše, predstavlja pozitivni izazov koji poziva na promišljanje teologije stvaranja u kontekstu evolucijske teorije. Veći problem predstavljaju dva oprječna ekstrema, s jedne strane ekstremni ateistički evolucionizam koji odbacuje pojam stvaranja i nudi redukcionističku antropologiju, $\mathrm{s}$ druge strane radikalni kreacionizam $\mathrm{u}$ ruhu suvremenoga Intelligent Designa koji, ignorirajući znanstvene spoznaje, biblijskom tekstu objave pristupa na doslovan način. Još veću opasnost ne samo kršćanskoj antropološkoj viziji nego cijelomu čovječanstvu predstavljaju ideološke političke zlouporabe teorije evolucije te instrumentalizacija spomenutih dvaju ekstrema i njihovih meduoblika. $^{31}$

Iz perspektive crkvenoga učiteljstva prekretnicom se smatra enciklika Providentissimus Deus pape Leona XIII. iz 1893. godine. Polazeći od logične postavke da istina istini ne može protusloviti, Papa poziva na pozitivno vrjednovanje vlastitih domena znanosti i teologije te poziva bibličare i teologe na poznavanje prirodoslovnih spoznaja kako bi se iste moglo kritički sagledati te odbaciti neutemeljene napade na vjeru.

\footnotetext{
${ }^{30}$ Usp. isto, 125-129.

${ }^{31}$ Usp. I. KEŠINA, Stvaranje i evolucija, u: Bogoslovska smotra 76(2006.)2, 363-394., ovdje 373-379.
} 
Još veću prekretnicu predstavlja enciklika Humani generis pape Pija XII. iz 1950. godine, u kojoj se teoriji evolucije pristupa kao prirodoslovnoj teoriji koja nije protivna postavkama kršćanske teologije stvaranja. Polazeći od razlikovanja tjelesnoga i duhovnoga aspekta ljudske egzistencije, ovdje se dopušta rasprava o porijeklu ljudskoga tijela u kontekstu teorije evolucije, ne isključujući posebnost čovjekova intimna odnosa s Bogom zahvaljujući osobnom poimanju duše stvorene izravno od Boga. Time se ujedno otvara prostor za kasniji razvoj teološko-filozofskih istraživanja koja idu ukorak s razvojem znanosti iz znanstvenih teorija o evoluciji, uz istovremeno razlikovanje vlastitosti domena znanosti i teologije. ${ }^{32}$

U duhu svojih prethodnika i smjernica II. vatikanskoga sabora nastavlja se papinska misao i intervencija Ivana Pavla II. koji datosti Objave sadržane u biblijskoj Knjizi Postanka (Post 1-3) smatra teološkim, a ne prirodoslovnim izričajima, te im se stoga ne može pristupati i tumačiti ih na doslovan način. Naprotiv, u svjetlu teorije o evoluciji, Božji čin stvaranja promatra se kao creatio continua, trajni proces koji se ne ograničava na inicijalni čin stvaranja, nego se nastavlja kao trajno održavanje i usavršavanje stvorenja. $U$ tom smislu znanstvene i teološke činjenice nisu $u$ suprotnosti, nego se međusobno nadopunjuju kao dva različita i komplementarna aspekta ljudske spoznaje. Čovjeku se pritom zadržava poseban status u odnosu na ostala stvorenja, upravo zbog njegove stvorenosti »na sliku Božju « koja mu jamči dostojanstvo osobe te određuje i usmjerava smisao ${ }^{33}$ njegove egzistencije. Samim time biva isključeno i neprihvatljivo materijalističko-redukcionističko tumačenje teorije evolucije te svi oblici antropološkoga redukcionizma. ${ }^{34} \mathrm{U}$ kontekstu tih postavki nastavit će se razvoj teološke misli brojnih katoličkih teologa dvadesetoga stoljeća s posljedičnim praktičnim aktualnim pastoralnim smjernicama. ${ }^{35}$

\footnotetext{
${ }^{32}$ Usp. isto, 380-381.

${ }^{33} \mathrm{Za}$ više o promišljanju fenomena smisla u kontekstu odnosa teologije i kognitivnih znanosti, vidi u: L. OVIEDO, Meaning and Religion: Exploring Mutual Implications, 25-46.

${ }^{34}$ Usp. I. KEŠINA, Stvaranje i evolucija, 381-384.

${ }^{35}$ Među vodećim teolozima ističemo Karla Rahnera: P. OVERHAGE, K. RAHNER, Das Problem der Hominisation. Über den biologischen Ursprung des Menschen, Freiburg, ${ }^{3} 1965$. Od domaćih autora predlažemo teološka promišljanja sljedećih autora: V. BAJSIĆ, Granična pitanja religije i znanosti. Studije i članci, S. Kušar (ur.), Zagreb, 1998.; N. BIŽACA, Božje djelovanje u svijetu dinamičkih procesa. Za jedan dijaloško-konvergentni model odnosa teologije i prirodnih znanosti, u: Filozofska istraživanja 23(2003.)4, 931-955.; T. MATULIĆ, Sloboda i racionalnost u svjetlu evolucionizma kao totalnoga svjetonazora ili: Pitanje o čovjeku u svjetlu stvaranja i evolucije?, u: Diacovensia 20(2012.) 1, 25-52. Za pastoralne smjernice predlažemo: I. KEŠINA, Stvaranje i evolucija, osobito 363-394.; N. VRANJEŠ, T. MILETIĆ, Teorija evolucije u suvremenom pastoralno-katehetskom kontekstu, u: Riječki teološki časopis 21(2013.)2, 467-492.; VIJEĆE HBK ZA NAUK VJERE, Čovjek stvoren na »sliku Božju « - njegova veličina i poziv, Zagreb, 2019., osobito br. 6.
} 


\section{Zaključak}

Kršćanska antropologija ne odriče se cjelovite antropološke vizije unutar koje se čovjeka promatra u sljedećim kontekstima: otajstvenosti, kao nikada do kraja spoznajno iscrpiv; jedinstvenosti i cjelovitosti, unatoč složenosti vlastite naravi; otvorenosti za transcendenciju, $\mathrm{s}$ trajnom potrebom nadilaženja samoga sebe i sveukupne stvorene i konačne stvarnosti; dijaloške naravi i relacionalnosti, $\mathrm{u}$ horizontalnom $\mathrm{i}$ vertikalnom aspektu - kao biće konstitutivne upućenosti na drugoga čovjeka i na samoga Boga. Samim time čovjeka se poima kao homo religiosus, kao biće »sposobno $\ll$ za Boga i u trajnoj potrazi za njime. ${ }^{36}$

Smatramo da upravo taj i takav čovjek predstavlja dodirnu točku teološke antropologije i znanosti općenito, pa tako i (evolutivne) kognitivne znanosti o religiji. Čovjek je zajedničko područje znanosti i teologije. On je taj koji pita, umuje i istražuje. U tom smislu on predstavlja interogativni subjekt ljudske spoznaje, ali je on istovremeno i objekt i primatelj sveukupnoga ljudskoga spoznavanja. On je zajednička tema, polazišna točka i mjesto susreta teologije i znanosti. On je »skriveni sastojak « svake spoznaje, reći će Karl Rahner. ${ }^{37}$ Upravo u tom pogledu smatramo kako scijentizam i reduktivnost u smislu samo je jedno objašnjenje istinito nisu nužni. Poštujući drvo znanstvenih disciplina i njihove različite razine objašnjenja te opravdanost i valjanost pojedinih znanstvenih objašnjenja određenih fenomena, uviđamo kako je moguća plodna suradnja teološke antropologije i (evolutivne) kognitivne znanosti o religiji. Upravo povijesni pregled znanstvenih izazova koji su bili stavljeni pred teološku antropologiju, kao i glavne karakteristike (evolutivne) kognitivne znanosti o religiji, pokazuju kako je pred nama dug put. Međusobni odnos poštovanja i uvažavanja, ali i zajedničkoga truda, trebao bi biti u prvom planu ako se želi približiti složenom fenomenu ljudske religioznosti, koji se proteže kroz brojne znanstvene discipline. Bojazan kako bi znanstvena slika religije ili (evolutivna) kognitivna znanost o religiji mogla u potpunosti umiroviti teologiju ili filozofiju religije nije opravdana. Naime jedna znanstvena teorija može u potpunosti potisnuti drugu (znanstvena revolucija) ili napredovati mnogo dalje od druge (znanstvena evolucija) samo na području jedne te iste znanstvene discipline. Kada je riječ o različitim znanstvenim poljima i razinama, onda treba uvažiti pluralizam objašnjenja te uvidjeti nemogućnost znanstvene revolucije ili evolucije. ${ }^{38}$

\footnotetext{
${ }^{36}$ Usp. R. PAVLIĆ, Sposobnost današnjeg čovjeka za vjeru. Homo capax (fi)dei, u: Bogoslovska smotra 83(2013.)1, 37-51.

${ }^{37}$ Usp. K. RAHNER, La teologia nel dialogo interdisciplinare delle scienze, u: ISTI, Nuovi saggi, Roma, 1975., 129.; I. SIVIGLIA, Antropologia teologica in dialogo, 54-59.

${ }^{38}$ Usp. R. N. MCCAULEY, E. T. LAWSON, Philosophical Foundations of the Cognitive Science of Religion, 20. i dalje.
} 
U skladu s navedenim poimanjem čovjeka i sama teološka antropologija nužno otkriva svoju dijalošku narav. Njezin doprinos (evolutivnoj) kognitivnoj znanosti o religiji možemo tražiti upravo u njezinoj dijaloškoj otvorenosti prema pozitivnoinduktivnom karakteru ljudske spoznaje, pri čemu su upravo spoznajni procesi i mehanizmi u temelju te nove znanstvene discipline. Hermeneutički ključ otvorenosti teološke antropologije predstavlja Kristovo čovještvo te inkarnacijski karakter kršćanske objave. ${ }^{39}$

Kršćansko je vjerovanje da je Bog u jednom trenutku ljudske povijesti uzeo ljudsku narav. U skladu s tim, sa stajališta kršćanske antropologije, dodirnu točku između teologije i znanosti, u ovom slučaju (evolutivne) kognitivne znanosti o religiji, moguće je naći s jedne strane kroz pozitivno vrjednovanje čovjekove povijesnosti, tjelesnosti i iskustva, $s$ druge strane onkraj materijalizma, biologizma, sociologizma i drugih antropoloških redukcionizama, odnosno u priznavanju znanstveno do kraja nedokučivih aspekata čovjekova bića.

${ }^{39}$ Usp. I. SIVIGLIA, Antropologia teologica in dialogo, 317-320. 
- S. Horvat - R. Pavlić, TeološKa antropologija Pred iZazovom ..., Str. 303-317.

\title{
THEOLOGICAL ANTHROPOLOGY MEETING THE CHALLENGE OF THE (EVOLUTIONARY) COGNITIVE SCIENCE OF RELIGION
}

\author{
Saša HORVAT* ${ }^{*}$ Richard PAVLIĆ ${ }^{* *}$
}

Summary: In the article the authors provide insights into the basic determinants of relatively young scientific disciplines - the cognitive science of religion and the evolutionary cognitive science of religion, which have become inevitable in attempting to pursue the scientific explanation of religion. The aim of the article is to provide a broader framework for understanding the possible future development of interdisciplinary and transdisciplinary dialogue between emerging disciplines and theological anthropology.

Keywords: cognitive science of religion, theological anthropology, religiosity, evolution, reduction, interdisciplinarity, God.

* Asst. Prof. Saša Horvat, Ph. D., Catholic Faculty of Theology, Theology in Rijeka, University of Zagreb, Omladinska 14, 51000 Rijeka, Croatia, horvat.sasa@gmail.com

** Asst. Prof. Richard Pavlić, Ph. D., Catholic Faculty of Theology, Theology in Rijeka, University of Zagreb, Omladinska 14, 51000 Rijeka, Croatia, ripavlic@gmail.com 